\title{
PLWHA's Perspective on Community Stigma for Getting Social Support and Improving Life Quality in the Digital Era
}

\author{
Rio Ady Erwansyah ${ }^{1}$, Moses Glorino Rumambo Pandin ${ }^{2}$ \\ ${ }^{1}$ Student of Doctoral Program in Nursing, Faculty of Nursing, Airlangga University \\ ${ }^{2}$ Faculty of Humanities, Airlangga University
}

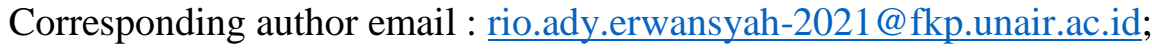

moses.glorino@fib.unair.ac.id

\begin{abstract}
Community stigma against HIV/AIDS is still a problem that must be faced by people living with HIV/AIDS (PLWHA). The existence of stigmatization and discrimination received by PLWHA causes the lack of social support they get. Social support is very important for PLWHA to improve their quality of life. In this digital era where the development of technology and social media is an alternative for PLWHA to get social support online through their community, by sharing information and experiences. This systematic review was conducted through Scopus, Science Direct, ProQuest, and SAGE. The selection of articles followed inclusion criteria, including articles published in the last five years and published in English and discussing perspectives on stigma. Articles published not in English and articles with unclear literature reviews were excluded from this study. The PRISMA flow chart and JBI assessment checklist were used to assess the risk of bias and article quality. 20 relevant articles will be reviewed. The results of the study found that in this digital era PLWHA can take advantage of technological developments and social media to improve their quality of life by getting social support through the online communities they follow.
\end{abstract}

Keywords: Social Support, Stigma, PLWHA/ODHA, HIV, AIDS

\section{Background}

Stigma against HIV/AIDS remains a significant barrier to public health worldwide and a major barrier to HIV/AIDS treatment, prevention, and support. Stigma against people living with HIV/AIDS (PLWHA) leads to reduced economic income and increased isolation from family and friends regarding their HIV status ${ }^{1}$. PLWHA often experience physical, psychological, social, and spiritual suffering, which harms their quality of life ${ }^{2-3}$

PLWHA face several difficulties when they try to achieve a satisfactory quality of life, from disturbances in their life history, disturbances in interpersonal and work relationships that can cause social isolation, and worsen social relationships that can harm their mental and physical health ${ }^{4}$. In this digital era, it is still difficult for them to adapt to their current status changes regarding the diagnosis they receive. Stigma and community discrimination against HIV/AIDS are still considered a major problem in the survival of PLWHA, making it difficult for them to get social support from both the community and family. Whereas social support 
from the community, especially families, can help PLWHA improve their quality of life and assist in the acceptance and disclosure of their serostatus.

\section{Objective}

The purpose of this systematic review is to explore the perspective of PLWHA on community stigma in obtaining social support and improving their quality of life in the digital age.

\section{Methodology}

This research is a review of articles conducted to find out the perspective of PLWHA in the digital era. The checklist and flow chart of reporting items for systematic review (PRISMA) was used to present the results of the systematic review. We entered electronic databases to find relevant articles such as Scopus, Science Direct, ProQuest, and SAGE. The literature search process was determined in a recent study of the last five years. There are no regulatory restrictions, but only articles published in English are reviewed. The feasibility of this study was assessed using the PICOT framework as below.

\section{Table 1 Picot Framework}

\section{PICOT Framework}

Population

Intervention

Comparator

Output

Time

\author{
Inclusion Criteria \\ PLWHA \\ Explore experiences and perspectives \\ No comparator \\ PLWHA perspective \\ 2017-2020
}

Articles are identified with the keywords "perspective, PLWHA, HIV, AIDS".

\section{Bias Risk}

The risk of bias can be reduced by using critical assessment tools. The review used a critical assessment tool from the Joanna Briggs Institute (JBI). The JBI assessment tool is a checklist questionnaire with a list of required items, things to do, and points to consider. Each research design has different questions. Researchers must assess the articles that have been selected. The scoring results come from low risk, medium risk, high risk, or unclear risk.

Inclusion and exclusion criteria: the articles used, filtered, and selected based on the inclusion criteria that have been set with the provisions of 5 years from 2017 to 2021, contain a discussion of perspectives on stigma. Articles that pass the inclusion criteria are then eliminated by the exclusion criteria. Exclusion criteria were referred to when the article was not written in English, the article was more than five years old, and the literature had an unclear review. The data that has been obtained is reviewed and then selected to be further grouped and discussed based on the points 


\section{Result}

An initial keyword search of the literature yielded 395 articles (59 from Scopus, 87 from Science Direct, 218 from ProQuest, and 31 from SAGE). After a review, 125 articles were eliminated because the population did not match the research objectives, the articles did not use English, and were not open access. Then 169 articles were excluded based on the last five years and did not include a literature review, and 101 complete articles that were assessed for eligibility were eliminated 81 articles because the articles did not discuss perspectives and the literature had an unclear review so that 20 articles were obtained that were following the feasibility of the study.
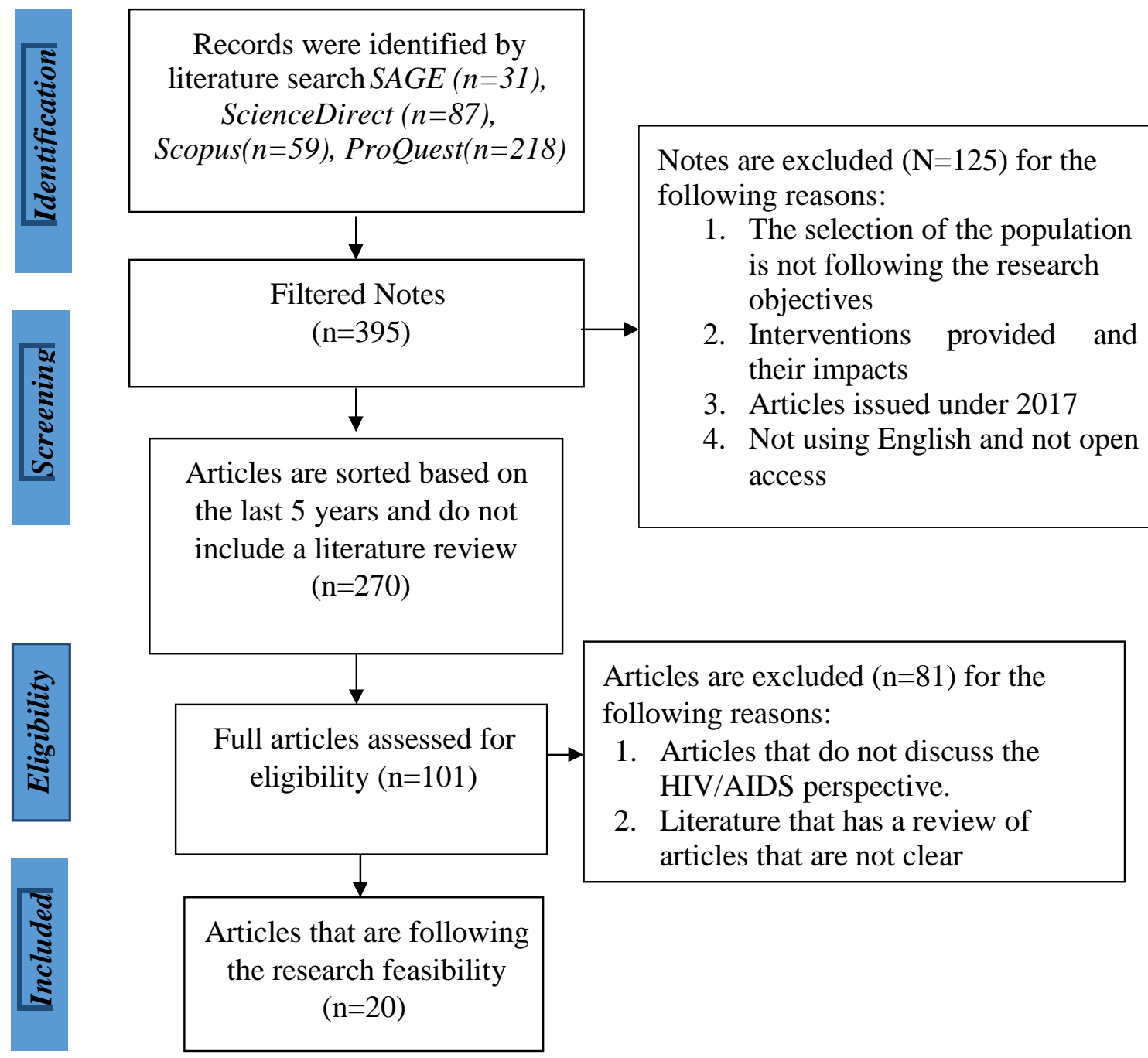

Figure 1 The results of the literature selection are summarized in the PRISMA flow diagram

The risk of bias in the articles that we found can be seen in the following table: 
medRxiv preprint doi: https://doi.org/10.1101/2022.01.17.22269334; this version posted January $19,2022$. The copyright holder for this preprint (which was not certified by peer review) is the author/funder, who has granted medRxiv a license to display the preprint in perpetuity.

It is made available under a CC-BY-NC-ND 4.0 International license.

Table 2 Risk assessment bias using the JBI critical assessment checklist

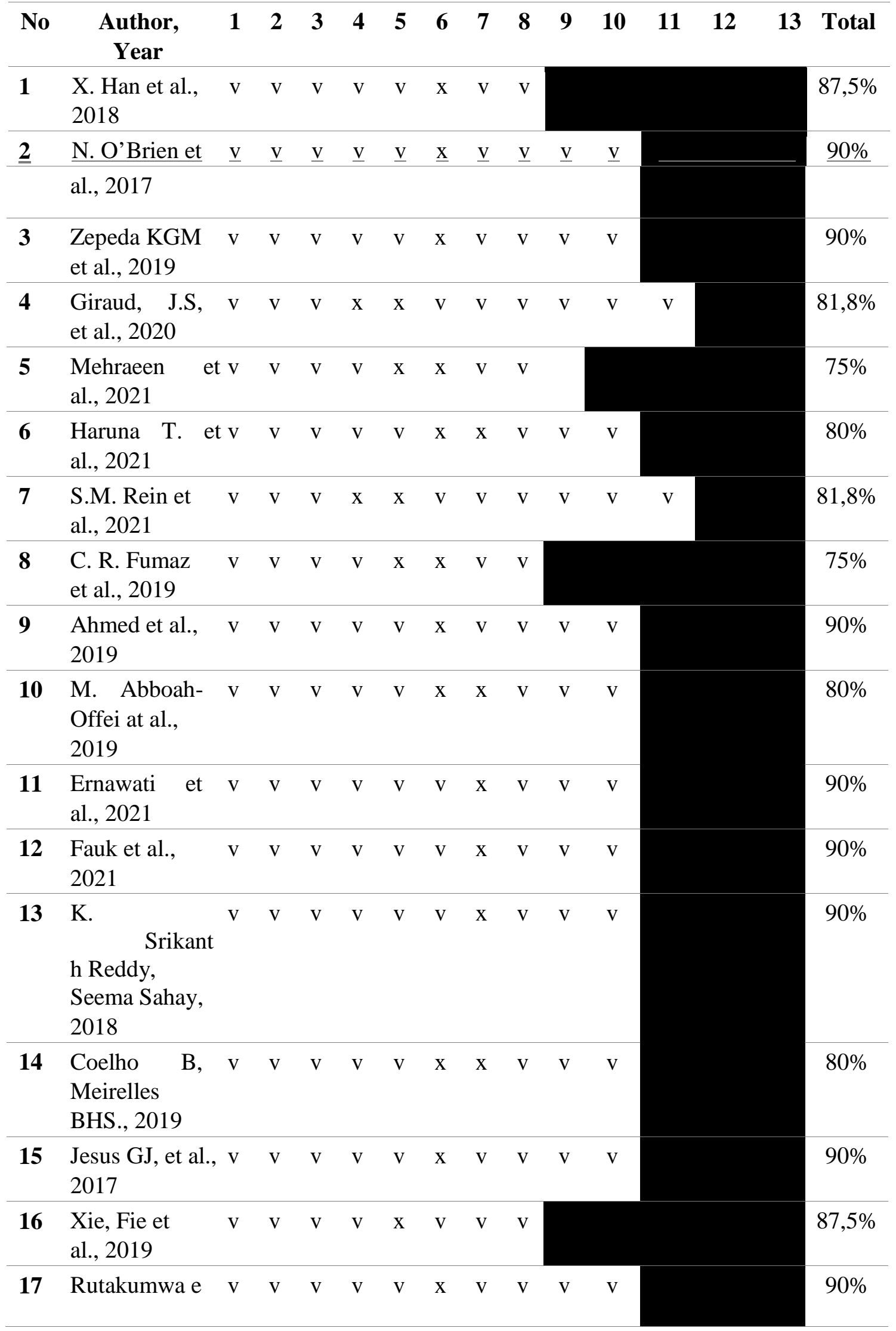




\begin{tabular}{|c|c|c|c|c|c|c|c|c|c|c|c|}
\hline & $\mathrm{t}$ al., 2021 & & & & & & & & & & \\
\hline 18 & $\begin{array}{l}\text { Rice et al., } \\
2018\end{array}$ & $\mathrm{v}$ & $\mathrm{v}$ & $\mathrm{V}$ & $\mathrm{v}$ & $\mathrm{x}$ & $\mathrm{X}$ & $\mathrm{v}$ & $\mathrm{v}$ & $\mathrm{v}$ & $80 \%$ \\
\hline 19 & $\begin{array}{l}\text { Cherry S. at al., v } \\
2018\end{array}$ & $\mathrm{v}$ & $\mathrm{v}$ & $\mathrm{v}$ & $\mathrm{v}$ & $\mathrm{v}$ & $\mathrm{x}$ & $\mathrm{v}$ & $\mathrm{v}$ & $\mathrm{v}$ & $90 \%$ \\
\hline 20 & $\begin{array}{l}\text { N. S. Perry et v } \\
\text { al., } 2017\end{array}$ & $\mathrm{v}$ & $\mathrm{v}$ & $\mathrm{v}$ & $\mathrm{v}$ & $\mathrm{x}$ & $\mathrm{v}$ & $\mathrm{v}$ & $\mathrm{v}$ & $\mathrm{v}$ & $90 \%$ \\
\hline
\end{tabular}

The Joanna Briggs Institute (JBI) Critical Assessment was used to assess and analyze the methodological quality of the articles obtained $(n=20)$. As agreed by the researcher himself that the final score of the methodological quality assessment if it reaches a minimum of $75 \%$ meets the critical assessment criteria, the article will be included for further data synthesis. All articles $(n=20)$ at the last screening achieved a score higher than $75 \%$ so they were ready for data synthesis.

Based on table 2, 14 articles were assessed for risk of bias using the JBI Critical Assessment Checklist for Qualitative Studies and the results were: a score of 90\% ( $\mathrm{n}=10$ articles) (N. O'Brien et al., 2017, Zepeda KGM et al. ., 2019, Ahmed et al., 2019, Ernawati et al., 2021, Fauk et al., 2021, K. Srikanth Reddy, Seema Sahay, 2018, Jesus GJ, et al., 2017, Rutakumwa et al., 2021, Cherry S. at al., 2018, NS Perry et al., 2017), score 80\% ( $\mathrm{n}=4$ articles) (Haruna T. et al., 2021, M. AbboahOffei at al., 2019, Coelho B, Meirelles BHS., 2019, Rice et al., 2018)

4 articles were assessed for risk of bias using the JBI critical assessment checklist for the Cross-Sectional Study and the results were: a score of $87.5 \%(\mathrm{n}=2$ articles) (X. Han et al., 2018, Xie, Fie, et al., 2019), score 75\% (n=2 articles) (CR Fumaz et al., 2019, Mehraeen et al., 2021).

2 articles were assessed for risk of bias using the JBI critical appraisal checklist for a cohort study and the results were: a score of $81.8 \%$ ( $n=2$ articles) (Giraud, J.S, et al., 2020, S.M. Rein et al., 2021). Based on the identification in table 1, 20 articles were assessed for risk of bias using the JBI critical assessment checklist for the design of Cross-Sectional Study, Cohort Study, Prevalence Study, and QuasiExperimental Study. The results found were 20 articles had scores above $75 \%$.

This systematic review was heterogeneous, with 14 articles using qualitative methods in the study, 4 cross-sectional articles, and 2 cohort articles. Results from selected articles using single and combined survey interventions. The sample varies because the journals selected are heterogeneous. The types of interventions provided are described in the following table:

1. Weibo friends with benefits for people living with HIV/AIDS? The implications of Weibo use for enacted social support, perceived social support, and health outcomes

With the development of social media. Online support is becoming increasingly important for people with health problems such as HIV/AIDS to seek social support. Where the platform generates discussions on various health topics and becomes a place to share information and experiences ${ }^{5-6}$ 
2. Envisioning Women-Centered HIV Care: Perspectives from Women Living with HIV in Canada

A women-centered approach to HIV care is critical to guiding policy and practice to improve care and outcomes for women living with HIV ${ }^{7}$.

3. Management of nursing care in HIV/AIDS from a palliative and hospital perspective

In the context of palliative care, actions to improve comfort and quality of life are emphasized in the physical, socio-cultural, and psycho-spiritual fields in an altruistic way, to put oneself in the position of others to jointly try to understand the suffering of patients and families ${ }^{8}$

4. De-simplifying single-tablet antiretroviral treatments for cost savings in France: From the patient perspectives to a 6-month follow-up on generics Simplification of ART treatment to generic drugs allows cost savings in health care costs ${ }^{9}$

5. Investigating the contributing factors to HIV/AIDS infection from the perspective of HIV-infected patients

An important cause of the spread of HIV is the government's weakness in public health education, family and individual factors ${ }^{10}$

6. Factors hindering the integration of care for non-communicable diseases within HIV care services in Dar es Salaam, Tanzania: The perspectives of health workers and people living with HIV

NCD service bundling in HIV care and treatment clinics has adequate treatment adherence support to improve quality of life, close monitoring of biomarkers that can predict the development of NCDs and social support providers ${ }^{11}$

7. Prospective association of social circumstance, socioeconomic, lifestyle, and mental health factors with subsequent hospitalization over 6-7 year follow up in people living with HIV

Current markers of socioeconomic disadvantage (non-employment, insecure housing situations, and financial difficulties) are strong predictors of hospitalization among PLWHA ${ }^{12}$

8. Health-related quality of life of people living with HIV infection in Spain: a gender perspective

The stereotypic differences associated with each sex may explain the perceived differences in quality of life. Men adopt healthy behaviors, helping to improve physical and mental health, emotional status, and a better quality of life through physical exercise. While women appear to be affected by their quality of life by personal experiences of rejection, receiving social stigma from various community sources affects their physical health and coping strategies used in response to HIV-related stress ${ }^{13-14}$

9. Facilitators and Barriers Affecting Adherence Among People Living With HIV/AIDS: A Qualitative Perspective

Quality nursing outcomes depend on patient medication adherence. Lack of social support and poor doctor-patient communication often force patients to bear the burden of illness that affects their social and psychological well-being 15 
10. How can we achieve person-centered care for people living with HIV/AIDS? A qualitative interview study with healthcare professionals and patients in Ghana PCC as care delivered in the community, free from stigma and discrimination, that addresses financial, human, and time resource issues ${ }^{16}$

11. Life Experiences in Parenting: The Perspective of Women with HIV-AIDS The form of hope for negative HIV status from loved ones, the lamentation of wives with PLWHA status in the hope that they will remain healthy and hope that their children will not experience the same disease ${ }^{17}$

12. HIV Stigma and Discrimination: Perspectives and Personal Experiences of Healthcare Providers in Yogyakarta and Belu, Indonesia

Stigma and discrimination are major challenges facing PLWHA globally because of their HIV status. Lack of knowledge about HIV, fear of being infected, personal values, religious thoughts, and socio-cultural values and norms are the driving forces for HIV-related stigma ${ }^{18}$

13. Advocacy for HIV/TB co-infection collaborative policy and service delivery in India: a civil society perspective

HIV prevention is a priority for TB control, and TB care and prevention is a priority for HIV/AIDS programs ${ }^{19}$

14. Care sharing for people with HIV/AIDS: a look targeted at young adults

The Health Care Network $(\mathrm{HCN})$ is an organization that regulates health services, including technology, which are interconnected by support systems, seeking to ensure comprehensive care ${ }^{20}$

15. Difficulties of living with HIV/Aids: Obstacles to quality of life

The impact of living with a chronic disease that still carries a lot of stigma and prejudice is the biggest obstacle between these individuals and their quality of life $^{21}$

16. Social Capital Associated with Quality of Life among People Living with HIV/AIDS in Nanchang, China

Bonding social capital score has a positive effect on mental health summary and physical health summary ${ }^{22}$

17. Stakeholders' perspectives on integrating the management of depression into routine HIV care in Uganda: qualitative findings from a feasibility study Integrating depression management into routine HIV care is acceptable among key stakeholders ${ }^{23}$

18. Perceptions of Intersectional Stigma among Diverse Women Living with HIV in the United States

Women living with HIV experience interrelated forms of stigma. The complex social environment in which HIV-positive women navigate shapes their realities of life, life opportunities, and well-being ${ }^{24}$

19. "My determination is to live": Narratives of African-American Women Who Have Lived with HIV for 10 or More Years

Public health programs for long-term survivors, including ways to promote resilience, create opportunities for meaningful work, build skills and disclosure 
20. Learning to address multiple syndemics for people living with HIV through client perspectives on CBT

Future psychotherapeutic interventions for HIV syndromes and treatments address complex issues comprehensively ${ }^{26}$

\begin{tabular}{|c|c|c|c|}
\hline No & Article Title & Intervention & Result \\
\hline 1 & $\begin{array}{l}\text { Weibo friends with } \\
\text { benefits for people } \\
\text { living with HIV/AIDS? } \\
\text { The implications of } \\
\text { Weibo use for enacted } \\
\text { social support, } \\
\text { perceived social } \\
\text { support, and } \\
\text { health outcomes }\end{array}$ & $\begin{array}{l}\text { Filling out online } \\
\text { questionnaires for } \\
\text { HIV/AIDS positive } \\
\text { Weibo users }\end{array}$ & $\begin{array}{l}\text { Better socioeconomic } \\
\text { conditions and poorer } \\
\text { physical conditions were } \\
\text { associated with higher } \\
\text { PSS-ON rates. PLWHA } \\
\text { experiences a higher level } \\
\text { of social support via } \\
\text { Weibo than offline. }\end{array}$ \\
\hline 2 & $\begin{array}{l}\text { Envisioning } \\
\text { WomenCentered HIV } \\
\text { Care: Perspectives from } \\
\text { Women Living with } \\
\text { HIV in Canada }\end{array}$ & $\begin{array}{l}\text { Conduct focus group } \\
\text { discussions with } \\
\text { semistructured } \\
\text { interviews to listen to the } \\
\text { experiences of women } \\
\text { living with HIV before } \\
\text { shifting to women's } \\
\text { perspectives on a } \\
\text { women-centered }\end{array}$ & $\begin{array}{l}\text { Women envision the } 3 \\
\text { main characteristics of } \\
\text { women-centered HIV } \\
\text { care: coordinated and } \\
\text { integrated services that } \\
\text { address HIV and women's } \\
\text { health care priorities that } \\
\text { protect against exclusion } \\
\text { from }\end{array}$ \\
\hline & & approach to HIV care & $\begin{array}{l}\text { treatment because of } \\
\text { stigma, care that } \\
\text { recognizes and responds } \\
\text { to structural barriers, and } \\
\text { cares that encourages peer } \\
\text { support and leadership. } \\
\text { same age }\end{array}$ \\
\hline 3 & $\begin{array}{l}\text { Management of nursing } \\
\text { care in HIV/AIDS from } \\
\text { a palliative and hospital } \\
\text { perspective }\end{array}$ & $\begin{array}{l}\text { Conduct semi-structured } \\
\text { interviews in two sample } \\
\text { groups with } 17 \\
\text { participants }\end{array}$ & $\begin{array}{l}\text { Generating } \\
\text { understanding of the } \\
\text { relationship between nurse } \\
\text { interactions in the } \\
\text { management of nursing } \\
\text { care for people who have } \\
\text { clinical complications } \\
\text { caused by AIDS and its } \\
\text { relationship to palliative } \\
\text { care }\end{array}$ \\
\hline
\end{tabular}




\begin{tabular}{|c|c|c|c|}
\hline 4 & $\begin{array}{l}\text { De-simplifying } \\
\text { singletablet } \\
\text { antiretroviral treatments } \\
\text { for cost savings in } \\
\text { France: From the } \\
\text { patient perspectives to a } \\
\text { 6-month follow-up on } \\
\text { generics }\end{array}$ & $\begin{array}{l}98 \text { patients received a } \\
\text { two-tablet treatment } \\
\text { regimen containing the } \\
\text { generic drug. } \\
\text { received } \\
\text { Eviplera }{ }^{\circledR} \text { and } 38 \\
\text { received Triumeq }{ }^{\circledR} \text {, six } \\
\text { months later, a second } \\
\text { survey was administered } \\
\text { to patients }\end{array}$ & $\begin{array}{l}45 \text { patients received } \\
\text { treatment that did not } \\
\text { refuse simplified, } 37 \\
\text { refused and } 16 \text { did not } \\
\text { decide and followed the } \\
\text { decision offered by their } \\
\text { doctor }\end{array}$ \\
\hline 5 & $\begin{array}{l}\text { Investigating the } \\
\text { contributing factors to } \\
\text { HIV/AIDS infection } \\
\text { from the perspective of } \\
\text { HIV-infected patients }\end{array}$ & $\begin{array}{l}150 \text { patients with HIV } \\
\text { were interviewed and } \\
\text { filled out a medication } \\
\text { adherence questionnaire } \\
\text { and a mental health } \\
\text { standard questionnaire }\end{array}$ & $\begin{array}{l}\text { The results revealed that } \\
\text { the main cause of HIV } \\
\text { infection in men was an } \\
\text { injection of drugs and in } \\
\text { women was sexual } \\
\text { intercourse with an } \\
\text { infected individual. }\end{array}$ \\
\hline 6 & $\begin{array}{l}\text { Factors hindering the } \\
\text { integration of care for } \\
\text { non-communicable } \\
\text { diseases within HIV } \\
\text { care services in Dar es } \\
\text { Salaam, Tanzania: The } \\
\text { perspectives of health } \\
\text { workers and people } \\
\text { living with HIV }\end{array}$ & $\begin{array}{l}\text { A guided checklist was } \\
\text { observed for } 5 \text { days at } \\
\text { the HIV care and } \\
\text { treatment clinic on } 130 \\
\text { PLWHA who provided } \\
\text { PTM treatment services. } \\
\text { Then conducted } \\
\text { interviews with } 5 \text { CTC } \\
\text { managers, } 9 \text { health care } \\
\text { providers, and } 27 \\
\text { PLWHA }\end{array}$ & $\begin{array}{l}\text { There is a positive attitude } \\
\text { between PLWHA and } \\
\text { health workers towards } \\
\text { the } \\
\text { integration } \\
\text { noncommunicable disease } \\
\text { services in HIV care and } \\
\text { treatment clinics. This is } \\
\text { due to the perceived } \\
\text { benefits associated with } \\
\text { the integration of PTM } \\
\text { services in one clinic }\end{array}$ \\
\hline 7 & $\begin{array}{l}\text { Prospective association } \\
\text { of social circumstance, } \\
\text { socioeconomic, } \\
\text { lifestyle, and mental } \\
\text { health factors with } \\
\text { subsequent } \\
\text { hospitalization over 6-7 }\end{array}$ & $\begin{array}{l}\text { Conducted the ASTRA } \\
\text { study by recruiting } \\
\text { PLWHA from } 8 \text { HIV } \\
\text { outpatient clinics with a } \\
\text { total of } 798 \text { participants } \\
\text { and asking them to fill }\end{array}$ & $\begin{array}{l}\text { Socio-economic losses, } \\
\text { social conditions, } \\
\text { evidence of mental health } \\
\text { disorders, and adverse } \\
\text { lifestyle factors are } \\
\text { hospitalization } \\
\text { PLWHA for }\end{array}$ \\
\hline & $\begin{array}{l}\text { year follow up in people } \\
\text { living with HIV }\end{array}$ & $\begin{array}{l}\text { out a } \quad \begin{array}{r}\text { baseline } \\
\text { questionnaire from }\end{array} \\
\text { February } 2011 \text { to June } \\
2018\end{array}$ & \\
\hline
\end{tabular}




\begin{tabular}{|c|c|c|c|}
\hline 8 & $\begin{array}{l}\text { Health-related quality } \\
\text { of life of people living } \\
\text { with HIV infection in } \\
\text { Spain: } \\
\text { a gender perspective }\end{array}$ & 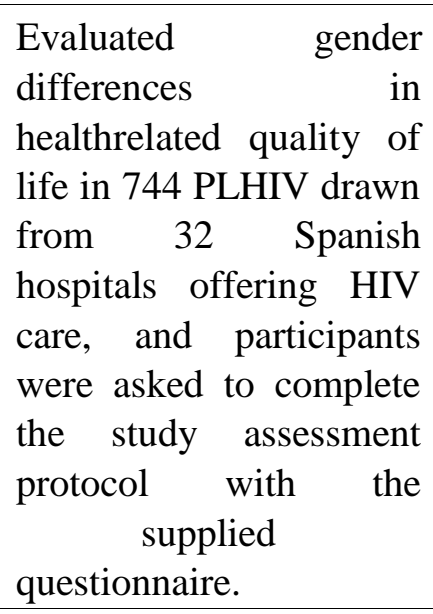 & $\begin{array}{l}\text { Women who showed } \\
\text { more emotional distress } \\
\text { and negative moods } \\
\text { related to their HIV } \\
\text { condition used less } \\
\text { positive coping strategies } \\
\text { and experienced more } \\
\text { rejection and stigma than } \\
\text { men. }\end{array}$ \\
\hline 9 & $\begin{array}{l}\text { Facilitators and Barriers } \\
\text { Affecting Adherence } \\
\text { Among People Living } \\
\text { With HIV/AIDS: A } \\
\text { Qualitative Perspective }\end{array}$ & $\begin{array}{lr}\text { Conduct } & \text { in-depth } \\
\text { interviews } & \text { with } 18- \\
\text { yearold } & \text { patients } \\
\text { diagnosed } & \text { with } \\
\text { HIV/AIDS } & \text { about } \\
\text { medication adherence }\end{array}$ & $\begin{array}{l}\text { Anxiety and stigma, the } \\
\text { negative perceived image } \\
\text { of HIV diagnosis, poor } \\
\text { support from the } \\
\text { community, and side } \\
\text { effects of treatment are } \\
\text { factors for treatment } \\
\text { nonadherence. }\end{array}$ \\
\hline 10 & $\begin{array}{l}\text { How can we achieve } \\
\text { person-centered care for } \\
\text { people living with } \\
\text { HIV/AIDS? } \\
\text { qualitative interview } \\
\text { study with healthcare } \\
\text { professionals and } \\
\text { patients in Ghana }\end{array}$ & $\begin{array}{l}\text { Conducted semi- } \\
\text { structured interviews } \\
\text { with PLWHA and health } \\
\text { professionals at the } \\
\text { community clinic aimed } \\
\text { at participants' } \\
\text { perspectives on their } \\
\text { illness, access to care, } \\
\text { involvement in } \\
\text { decisionmaking, their } \\
\text { symptoms, concerns, and } \\
\text { preferences for care. }\end{array}$ & $\begin{array}{l}\text { This study provides new } \\
\text { insights into what } \\
\text { patientcentered care } \\
\text { (PCC) is all about. People } \\
\text { with HIV understand PCC } \\
\text { as care that involves them } \\
\text { in their care decisions. }\end{array}$ \\
\hline 11 & $\begin{array}{l}\text { Life Experiences in } \\
\text { Parenting: The } \\
\text { Perspective of Women } \\
\text { with HIV-AIDS }\end{array}$ & $\begin{array}{l}\text { Conducted interviews } \\
\text { with wives who were } \\
\text { diagnosed with } \\
\text { HIV/AIDS and } \\
\text { registered by the HIV- } \\
\text { AIDS program at the } \\
\text { Serang City Health } \\
\text { Center, to explore the } \\
\text { phenomenon of mothers } \\
\text { with HIV/AIDS in } \\
\text { caring for their children. }\end{array}$ & $\begin{array}{l}\text { The results showed that } \\
\text { the mother wanted her } \\
\text { child or husband to have a } \\
\text { negative HIV status. }\end{array}$ \\
\hline
\end{tabular}




\begin{tabular}{|c|c|c|c|}
\hline 12 & $\begin{array}{l}\text { HIV Stigma and } \\
\text { Discrimination: } \\
\text { Perspectives and } \\
\text { Personal Experiences of }\end{array}$ & $\begin{array}{l}\text { Conducted interviews } \\
\text { with } 92 \text { PLWHA and } 20 \\
\text { health care providers } \\
\text { regarding stigma and }\end{array}$ & $\begin{array}{l}\text { Perspectives and } \\
\text { experiences of health care } \\
\text { providers regarding HIV } \\
\text { stigma and discrimination }\end{array}$ \\
\hline & $\begin{array}{l}\text { Healthcare Providers in } \\
\text { Yogyakarta and Belu, } \\
\text { Indonesia }\end{array}$ & $\begin{array}{l}\text { discrimination against } \\
\text { PLWHA }\end{array}$ & $\begin{array}{l}\text { still occur in families and } \\
\text { communities. Reflected in } \\
\text { negative labeling by } \\
\text { others }\end{array}$ \\
\hline 13 & $\begin{array}{l}\text { Advocacy for HIV/TB } \\
\text { co-infection } \\
\text { collaborative policy and } \\
\text { service delivery in India: } \\
\text { a civil society } \\
\text { perspective }\end{array}$ & $\begin{array}{l}\text { Conducted interviews } \\
\text { with } 26 \text { participants } \\
\text { consisting of } \\
\text { representatives of } \\
\text { advocacy organizations, } \\
\text { health activists and } \\
\text { PLWHA }\end{array}$ & $\begin{array}{l}\text { Civil society prioritizes } \\
\text { HIV/TB coinfection is an } \\
\text { important public health } \\
\text { issue and advocates } \\
\text { identifying common } \\
\text { indicators of coinfection } \\
\text { for better program } \\
\text { management }\end{array}$ \\
\hline 14 & $\begin{array}{l}\text { Care sharing for people } \\
\text { with HIV/AIDS: a look } \\
\text { targeted at young adults }\end{array}$ & $\begin{array}{l}\text { Conducting interviews } \\
\text { with } 19 \text { participants with } \\
\text { HIV/AIDS who were } \\
\text { divided into } 2 \text { groups } \\
\text { was shown to understand } \\
\text { the sharing of care for } \\
\text { PLWHA }\end{array}$ & $\begin{array}{l}\text { City governments have } \\
\text { transitioned into a model } \\
\text { of health care for people } \\
\text { with HIV/AIDS, whose } \\
\text { care is shared within the } \\
\text { health care network. }\end{array}$ \\
\hline 15 & $\begin{array}{l}\text { Difficulties of living } \\
\text { with HIV/Aids: } \\
\text { Obstacles to quality of } \\
\text { life }\end{array}$ & $\begin{array}{l}\text { Conducted interviews } \\
\text { with } 26 \text { PLWHA about } \\
\text { quality of life }\end{array}$ & $\begin{array}{l}\text { There are difficulties } \\
\text { faced by PLWHA. The } \\
\text { main difficulties cited are } \\
\text { prejudice experienced in } \\
\text { family and social contexts, } \\
\text { managing affective and } \\
\text { sexual partnerships, and } \\
\text { achieving quality of life }\end{array}$ \\
\hline 16 & $\begin{array}{l}\text { Social Capital } \\
\text { Associated with Quality } \\
\text { of Life among People } \\
\text { Living with HIV/AIDS } \\
\text { in Nanchang, China }\end{array}$ & $\begin{array}{l}225 \text { PLWHA in } \\
\text { Nanchang, China was } \\
\text { asked to fill out a } \\
\text { questionnaire to identify } \\
\text { social capital factors that } \\
\text { identify the quality of } \\
\text { life } \\
\text { in PLWHA }\end{array}$ & $\begin{array}{l}\text { People living with HIV } \\
\text { have low social capital } \\
\text { and poor quality of life in } \\
\text { Nanchang. Social bonding } \\
\text { capital has a positive } \\
\text { effect on the quality of life } \\
\text { of } \\
\text { PLWHA }\end{array}$ \\
\hline
\end{tabular}




\begin{tabular}{|c|c|c|c|}
\hline 17 & $\begin{array}{l}\text { Stakeholders' } \\
\text { perspectives } \\
\text { on integrating the } \\
\text { management of } \\
\text { depression into routine } \\
\text { HIV care in Uganda: } \\
\quad \text { qualitative } \\
\text { findings } \\
\text { from a feasibility study }\end{array}$ & $\begin{array}{l}\text { Conducted interviews } \\
\text { with } 11 \text { PLWHA } \\
\text { patients, doctors, } \\
\text { supervisors, and mental } \\
\text { health specialists and } \\
\text { group-focused } \\
\text { discussions by lay health } \\
\text { workers. Interviews were } \\
\text { conducted to evaluate } \\
\text { HIV+D Interventions }\end{array}$ & $\begin{array}{l}\text { Patients highlight the } \\
\text { benefits of treating } \\
\text { depression in the context } \\
\text { of HIV care, including } \\
\text { improved adherence to } \\
\text { antiretroviral therapy, } \\
\text { coping with sleeplessness, } \\
\text { and suicidal ideation, and } \\
\text { regaining a sense of } \\
\text { selfefficacy. }\end{array}$ \\
\hline \multirow[t]{2}{*}{18} & $\begin{array}{l}\text { Perceptions of } \\
\text { Intersectional Stigma } \\
\text { among Diverse Women } \\
\text { Living with HIV in the } \\
\text { United States }\end{array}$ & $\begin{array}{l}\text { Conducted interviews } \\
\text { with } 76 \text { women living } \\
\text { with HIV from various } \\
\text { socioeconomic } \\
\text { backgrounds }\end{array}$ & $\begin{array}{l}\text { Women living with HIV } \\
\text { feel many forms of stigma } \\
\text { apart from the stigma } \\
\text { associated with HIV. The } \\
\text { most common forms of } \\
\text { stigma and discrimination } \\
\text { are related to their gender, }\end{array}$ \\
\hline & & & race, and income level. \\
\hline 19 & $\begin{array}{l}\text { "My determination is to } \\
\text { live": Narratives } \\
\text { of African- } \\
\text { American } \\
\text { Women Who Have } \\
\text { Lived with HIV for } 10 \\
\text { or More Years }\end{array}$ & $\begin{array}{l}\text { Conducting interviews } \\
\text { with women living with } \\
\text { HIV for } 10 \text { years }\end{array}$ & $\begin{array}{l}\text { The need for specific } \\
\text { programs for long-term } \\
\text { survivors, including } \\
\text { resilience training, } \\
\text { educational programs on } \\
\text { dating and disclosure, and } \\
\text { opportunities to engage in } \\
\text { meaningful work or } \\
\text { volunteer initiatives }\end{array}$ \\
\hline 20 & $\begin{array}{l}\text { Learning to address } \\
\text { multiple syndemics for } \\
\text { people living with HIV } \\
\text { through client } \\
\text { perspectives on CBT }\end{array}$ & $\begin{array}{l}\text { Conduct interviews with } \\
\text { multiple comorbid } \\
\text { PLWHA who complete } \\
\text { cognitive-behavioral } \\
\text { therapy (CBT) }\end{array}$ & $\begin{array}{l}\text { Mental health issues are } \\
\text { interrelated and provide } \\
\text { an informative insight into } \\
\text { how participants perceive } \\
\text { the interconnections } \\
\text { between their mental } \\
\text { health diagnoses, and how } \\
\text { they behave in their } \\
\text { health. }\end{array}$ \\
\hline
\end{tabular}

\section{Discussion}

The findings from this systematic review found that the perspective of PLWHA on stigma where stigma is still a major problem in improving their quality of life. Research by Jesus GJ, et al. (2017) the impact of living with a chronic disease that still carries a lot of stigma and prejudice is the biggest obstacle to PLWHA regarding their quality of life ${ }^{7}$. It is difficult for PLWHA to improve their quality of life in community stigma that still exists today so that they do not receive 
social support in carrying out their lives. Through social support, especially family members, it is very important to help PLWHA accept their diagnosis and choose a healthy life and find ways to grow ${ }^{25}$.

Many PLWHA expressed their perspective that it was difficult for them to be involved in a social environment because of the stigmatization of their HIV/AIDS status and made it difficult for them to seek social support from friends and family members. With the social conditions of PLWHA like that, they also lack emotional support so this can have an impact on their clinical condition. In this digital era, the development of information technology and social media makes PLWHA try to find alternatives in overcoming their social problems. PLWHA can seek support through online communities that they can access via the internet, where they can get information about their illness and find a community that suits them, so they can share experiences and their daily lives. In this way, PLWHA can get the social support that has an impact on their quality of life-related to their emotional needs. In the research of X. Han et al. (2018) with the development of social media in the PLWHA community, they can receive social support from online communities, where they can exchange information and share their experiences, as well as seek the needed emotional support ${ }^{27}$.

In addition to the social support they seek through online communities, there is also a need for programs from the government that help PLWHA reduce the stigma they receive so that they can receive social support to improve their quality of life and their economic status. Several studies discuss the perspective of PLWHA about the need for programs to address social problems that occur. In the study of $\mathrm{M}$. AbboahOffei et al. (2019) PLWHA understands patient-centered care (PCC) programs not only involve them in making decisions about their care but also as a way to deal with broader social problems such as living a normal life like other people, getting married, having children and being employed ${ }^{16}$

The limitations and weaknesses of this research lie in the process and systematic review, where the researcher realizes that in a study there must be many obstacles and obstacles. One of the factors that became an obstacle in this study was the limitation of language and time, where the researcher used only a literature review that used English where had an effect on the results obtained.

\section{Conclusion}

In this digital era, the perspective of PLWHA on stigma is still the main problem they face. However, with the development of technology and social media, they can get support from the online community they follow, so they can share experiences in improving their quality of life.

\section{References}

1. Mak WWS, Mo PKH, Ma GYK, Lam MYY. Meta-analysis and systematic review of studies on the effectiveness of HIV stigma reduction programs. Soc Sci Med. 2017;188:30-40. doi:10.1016/j.socscimed.2017.06.045

2. Harding R, Simms V, Alexander C, et al. Can palliative care integrated within HIV outpatient settings improve pain and symptom control in a low-income 
country? A prospective, longitudinal, controlled intervention evaluation. AIDS Care. 2013;25(7):795-804. doi:10.1080/09540121.2012.736608

3. Harding R, Simms V, Penfold S, et al. Quality of life and wellbeing among HIV outpatients in East Africa: A multicentre observational study. BMC Infect Dis. 2014;14(1):1-10. doi:10.1186/s12879-014-0613-1

4. Macapagal KR, Ringer JM, Woller SE, Lysaker PH. Personal Narratives, Coping, and Quality of Life in Persons Living With HIV. J Assoc Nurses AIDS Care. 2012;23(4):361-365. doi:10.1016/j.jana.2011.08.011

5. Nambisan P. Information seeking and social support in online health communities: Impact on patients' perceived empathy. J Am Med Informatics Assoc. 2011;18(3):298-304. doi:10.1136/amiajnl-2010-000058

6. Robillard JM, Johnson TW, Hennessey C, Beattie BL, Illes J. Aging 2.0: Health Information about Dementia on Twitter. PLoS One. 2013;8(7):1-5. doi:10.1371/journal.pone.0069861

7. O'Brien N, Greene S, Carter A, et al. Envisioning Women-Centered HIV Care: Perspectives from Women Living with HIV in Canada. Women's Heal Issues. 2017;27(6):721-730. doi:10.1016/j.whi.2017.08.001

8. Cunha GH da, Galvão MTG, Pinheiro PN da C, Vieira NFC. Health literacy for people living with HIV/Aids: an integrative review. Rev Bras Enferm. 2017;70(1):180-188. doi:10.1590/0034-7167-2015-0052

9. Giraud JS, Doisne M, Wai ACH, et al. De-simplifying single-tablet antiretroviral treatments for cost savings in France: From the patient perspectives to a 6-month followup on generics. PLoS One. 2020;15(9 September):1-13. doi:10.1371/journal.pone.0239704

10. Mehraeen M, Heydari M, Lankarani KB, Joulaei H, Faghih M. Investigating the contributing factors to HIV/AIDS infection from the perspective of HIVinfected patients. BMC Psychol. 2021;9(1):1-9. doi:10.1186/s40359-021-00513W

11. Haregu TN, Setswe G, Elliott J, Oldenburg B. Integration of HIV/AIDS and noncommunicable diseases in developing countries: rationale, policies and models. Int J Healthc. 2015;1(1). doi:10.5430/ijh.v1n1p21

12. Rein SM, Smith CJ, Chaloner C, et al. Prospective association of social circumstance, socioeconomic, lifestyle and mental health factors with subsequent hospitalisation over 6-7 year follow up in people living with HIV. EClinicalMedicine. 2021;31:100665. doi:10.1016/j.eclinm.2020.100665

13. Nosrat S, Whitworth JW, Ciccolo JT. Exercise and mental health of people living with HIV: A systematic review. Chronic Illn. 2017;13(4):299-319. doi:10.1177/1742395317694224

14. Norcini Pala A, Steca P. Illness perceptions and coping strategies among individuals diagnosed with HIV. J Behav Med. 2015;38(4):620-631. doi:10.1007/s10865-015-9639-0 
15. Ahmed SI, Farooqui M, Syed Sulaiman SA, Hassali MA, Lee CKC. Facilitators and Barriers Affecting Adherence Among People Living With HIV/AIDS: A Qualitative Perspective. J Patient Exp. 2019;6(1):33-40. doi:10.1177/2374373518770805

16. Abboah-Offei M, Bristowe K, Koffman J, et al. How can we achieve personcentred care for people living with HIV/AIDS? A qualitative interview study with

healthcare professionals and patients in Ghana. AIDS Care - Psychol SocioMedical Asp AIDS/HIV. 2020;32(12):1479-1488. doi:10.1080/09540121.2019.1698708

17. Ernawati E, Rahmawati D, Wulandari I, Afriyani F. Life experiences in parenting: The perspective of women with hiv-aids. Open Access Maced $\mathrm{J}$ Med Sci. 2021;9(T4):35-43. doi:10.3889/oamjms.2021.5760

18. Fauk NK, Ward PR, Hawke K, Mwanri L. HIV Stigma and Discrimination: Perspectives and Personal Experiences of Healthcare Providers in Yogyakarta and Belu, Indonesia. Front Med. 2021;8(May):1-11. doi:10.3389/fmed.2021.625787

19. Reddy KS, Sahay S. Advocacy for HIV/TB co-infection collaborative policy and service delivery in India: A civil society perspective. HIV AIDS Rev. 2018;17(4):259-266. doi:10.5114/hivar.2018.80257

20. Coelho B, Meirelles BHS. Care sharing for people with HIV/AIDS: a look targeted at young adults. Rev Bras Enferm. 2019;72(5):1341-1348. doi:10.1590/0034-7167-2018-0248

21. Article O. Difficulties of living with HIV / Aids : Obstacles to quality of life. 2017;30(3):301-308.

22. Xie F, Zheng H, Huang L, Yuan Z, Lu Y. Social capital associated with quality of life among people living with HIV/AIDS in nanchang, China. Int J Environ Res Public Health. 2019;16(2):1-13. doi:10.3390/ijerph16020276

23. Rutakumwa R, Ssebunnya J, Mugisha J, et al. Stakeholders' perspectives on integrating the management of depression into routine HIV care in Uganda: qualitative findings from a feasibility study. Int $J$ Ment Health Syst. 2021;15(1):1-

15. doi:10.1186/s13033-021-00486-8

24. Watkins-Hayes C, Pittman-Gay LS Da, Beaman J. "Dying from" to "living with": Framing institutions and the coping processes of African American women living with HIV/AIDS. Soc Sci Med. 2012;74(12):2028-2036. doi:10.1016/j.socscimed.2012.02.001

25. Cherry S, De Marrais K, Keita C, Davis M, Lee J. "My determination is to live": Narratives of African-American women who have lived with HIV for 10 or more years. Qual Rep. 2019;23(10):2490-2510. doi:10.46743/2160$3715 / 2018.3389$ 
medRxiv preprint doi: https://doi.org/10.1101/2022.01.17.22269334; this version posted January 19, 2022. The copyright holder for this preprint (which was not certified by peer review) is the author/funder, who has granted medRxiv a license to display the preprint in perpetuity. It is made available under a CC-BY-NC-ND 4.0 International license.

26. Perry NS, Remmert JE, Psaros C, Pinkston M, Safren SA. Learning to address multiple syndemics for people living with HIV through client perspectives on CBT. Psychother Res. 2019;29(4):492-502. doi:10.1080/10503307.2017.1380863

27. Han X, Li B, Qu J, Zhu Q. Weibo friends with benefits for people live with HIV/AIDS? The implications of Weibo use for enacted social support, perceived social support and health outcomes. Soc Sci Med. 2018;211(June):157-163. doi:10.1016/j.socscimed.2018.06.016 